\title{
Evaluation of the Dietary Reference Intakes for Japanese (2010 Edition): Recommended Protein, Pantothenic Acid, Vitamin D, and Iron Intakes for Breast-Fed Infants Aged 6 - 11 Months
}

\author{
Setsuko Tsutie ${ }^{1}$, Nobutaka Kurihara ${ }^{1}$, Aki Sasaki ${ }^{2}$, Arisa Takagi ${ }^{3}$, Harumiti Seguti $^{1}$ Tetsuya Inatome $^{1}$ \\ ${ }^{1}$ Nutritional Science, Kobe Women's University, Hyogo, Japan; ${ }^{2}$ Faculty of Nursing and Human, Yamaguchi Prefectural University, Ya- \\ maguchi, Japan; ${ }^{3}$ Faculty of Human Health, Sonoda Women's University, Hyogo, Japan. \\ Email: tsuti@suma.kobe-wu.ac.jp
}

Received January $5^{\text {th }}, 2011$; revised February $25^{\text {th }}, 2011$; accepted March $2^{\text {nd }}, 2011$.

\begin{abstract}
Objective: With regard to the 2010 edition of Dietary Reference Intakes for Japanese (DRIs-2010), we investigated whether the DRIs for two age groups, breast-fed infants aged 6 - 8 and 9 - 11 months, can be fulfilled for every nutrient in actual dietary practice. Design: We evaluated 1) whether the DRIs for all nutrients can be fulfilled in a formula with energy and protein exceeding their DRIs, 2) whether the DRIs for all nutrients can be fulfilled in a formula prepared in accordance with Japanese government-recommended weaning guidelines, and 3) what kinds of formulas can be prepared if the DRIs for all nutrients are fulfilled without referring to the weaning guidelines. Setting: Simulation of diet menu on the basis of published data in our university and survey of diet menu in a university hospital attached to a national medical school. Subjects: The three types of formulas were planned for ten days. Results: It was impossible to simultaneously fulfil the DRIs for 6 - 8-month-old infants concerning pantothenic acid, vitamin D, and iron and those for 9 - 11-month-old infants concerning these nutrients plus protein. Conclusion: According to the DRIs-2010, the DRI for all nutrients could not be fulfilled in an ingestible formula.
\end{abstract}

Keywords: Dietary Reference Intakes, Breast-Fed Infants (6 - 11-Month-Old), Pantothenic Acid, Protein, Vitamin D, Iron

\section{Introduction}

The 2010 edition of Dietary Reference Intakes for Japanese established by the Ministry of Health, Labour and Welfare [1] (DRIs-2010) was released in May 2009 (Table 1). In the 2010 version [1], the DRIs for 6 - 11 -month-old infants have been increased for vitamins A and $\mathrm{D}$, decreased for manganese and iron, and unchanged for pantothenic acid, compared to the respective values in the 2005 version [2]. The previous DRIs for several other nutrients have also been revised upward or downward. In the National Health and Nutrition Survey in Japan [3], DRIs for 6 - 11-month-old infants are determined by conventional calculation methods and methods used overseas, because there have been no report concerning such infants, and their actual dietary intakes have not been clarified. Whether DRIs of all nutrients can be fulfilled by everyday menus is uncertain. In our previous report [4], we stated, "the contents of pantothenic acid, vitamin D, manganese, and iron were lower than DRIs and the vitamin A content exceeded the Tolerable Upper Intake Level (UL)," for 6 - 11-month-old breast-fed infants as recommended in the 2005 version of Dietary Reference Intakes for Japanese.

In this study, we evaluated whether formulas that fulfil the DRIs-2010 [1] for all nutrients can be prepared in compliance with the Recommendations for Conducting Weaning in the Guidebook for Supporting Feeding and Weaning [5] for 6 - 11-month-old breast-fed infants.

\section{Experimental Methods}

\subsection{Nutrient Content of Weaning Formulas and Types of Weaning Meals}

According to the DRIs, the estimated energy requirement of 6 - 11-month-old infants is lower in females than in 
Table 1. Revisions made in the 2010 Dietary Reference Intakes (DRI) for Japanese type of DRI.

\begin{tabular}{|c|c|c|c|c|}
\hline \multicolumn{3}{|c|}{ Type of DRI } & $\begin{array}{c}6-8 \\
\text { months }\end{array}$ & $\begin{array}{c}9-11 \\
\text { months }\end{array}$ \\
\hline \multirow{2}{*}{ Energy } & \multirow{2}{*}{ EER } & \multirow{2}{*}{ kcal } & Boy 650 & Boy 700 \\
\hline & & & Girl 600 & Girl 650 \\
\hline Protein & AI & g & 15 & 25 \\
\hline Fat-energy ratio & AI & $\%$ & & \\
\hline Vitamin $B_{1}$ & $\mathrm{AI}$ & $\mathrm{mg}$ & & \\
\hline Vitamin $B_{2}$ & AI & $\mathrm{mg}$ & & \\
\hline Niacin & AI & $\mathrm{mg}$ & & \\
\hline Vitamin $B_{6}$ & AI & $\mathrm{mg}$ & & \\
\hline Folic acid & AI & $\mu \mathrm{g}$ & & \\
\hline Vitamin $B_{12}$ & AI & $\mu \mathrm{g}$ & & \\
\hline Pantothenic acid & AI & $\mathrm{mg}$ & & \\
\hline Vitamin C & AI & $\mathrm{mg}$ & & \\
\hline \multirow{2}{*}{ Vitamin A } & AI & $\mu \mathrm{gR}$ & & \\
\hline & UL & E & & \\
\hline Vitamin E & AI & $\mathrm{mg}$ & & \\
\hline \multirow{2}{*}{ Vitamin D } & AI & \multirow{2}{*}{$\mu \mathrm{g}$} & & \\
\hline & UL & & & \\
\hline Vitamin $\mathrm{K}$ & AI & $\mathrm{mg}$ & & \\
\hline Magnesium & AI & $\mathrm{mg}$ & & \\
\hline Calcium & AI & $\mathrm{mg}$ & & \\
\hline Phosphorus & AI & $\mathrm{mg}$ & & \\
\hline Manganese & AI & $\mathrm{mg}$ & & \\
\hline \multirow{3}{*}{ Iron } & EAR & \multirow{3}{*}{$\mathrm{mg}$} & & \\
\hline & \multirow{2}{*}{ RDA } & & & \\
\hline & & & & \\
\hline Copper & AI & $\mathrm{mg}$ & & \\
\hline Zinc & AI & $\mathrm{mg}$ & & \\
\hline Potassium & $\mathrm{AI}$ & $\mathrm{mg}$ & & \\
\hline
\end{tabular}

DRI, dietary reference intakes; EER, estimated energy requirement; AI, adequate intake; UL, tolerable upper intake level; EAR, estimated average requirement; RDA, recommended dietary allowance. Biotin, iodine, selenium, chromium, and molybdenum were excluded from the evaluation, because they are not mentioned in the Standard Tables of Food Composition in Japan.

males, but the recommended nutrient intakes except that for iron are the same in males and females. In females, as each DRI must be met with a lower energy intake, menus are more difficult to prepare. In this study, we used the DRIs-2010 [1] for females aged $6-8$ and 9 - 11 months as the target energy/nutrient intakes.

From the weaning guidelines [5], the recommended food-group intakes for infants aged $7-8$ and $9-11$ months were selected as the target weaning meal intakes. The guidelines categorizes infants into four age groups ( 5 - 6-, 7 - 8-, 9 - 11-, and 12 - 18-month-old infants), and suggests adequate ranges of food-group intakes and food combinations by age group except for the $5-6$ - and 12 18-month-old infants. The target food-group intakes in this study were defined as follows: formulas for 6 - 8-month-old infants prepared according to the weaning guidelines' recommended food-group [5] intake for 7 - 8-month-old infants using the lower limit of the ranges (conditions under which the DRIs are difficult to fulfil); and formulas for 9 - 11-month-old infants prepared according to the weaning guidelines' recommended foodgroup [5] intake for 9 - 11-month-old infants using the upper limit of the ranges (conditions under which the DRIs are more likely to be fulfilled).

The nutrient contents of weaning meals were calculated using the Standard Tables of Food Composition in Japan (fifth revised edition) [6]. Since these food composition tables show fatty acid contents of only a small number of food items and did not describe biotin, iodine, selenium, chromium, and molybdenum, these nutrients were excluded from the present assessment.

\subsection{Types of Weaning Formulas}

We prepared the following weaning formulas: hospital formulas, which were based on the feeding regimens that were used in a hospital to provide energy and protein at levels above the DRIs-2010 [1]; formulas based on weaning guidelines, which were designed to provide energy and protein at levels equal to the DRIs-2010 and follow the weaning guidelines [5]; and conformity formulas, which were designed to maximally reflect the DRI-2010 for each nutrient without following the weaning guidelines. Furthermore, since the formulas based on weaning guidelines were eventually found not to satisfy the DRIs-2010 for pantothenic acid, vitamin D, and iron for both age groups, and protein for 9 - 11-month-old infants, we modified the formulas based on weaning guidelines to fulfil one of these nutrients (hereafter designated formulas with $100 \%$ DRI for pantothenic acid, vitamin $\mathrm{D}$, iron, or protein).

\subsection{Food-Group and Nutrient Contents}

With regard to weaning meals incorporating each weaning formula, their food-group contents (per one meal) were calculated by the categories of grains (group I), vegetables and fruits (group II), and protein sources including fish, meat, tofu, eggs, and dairy products (group III), averaged over 10 days, and expressed as percentages relative to the target food-group intakes (per one meal) recommended in the weaning guidelines [5] (Table 2).

The target energy/nutrient intake levels based on the DRIs-2010 were further defined as follows: estimated energy requirement, (EER); iron (for which an adequate intake (AI) has not been determined), recommended dietary allowance (RDA); and other nutrients, AI. The energy and nutrient contents (mean over 10 days) were 
Table 2. Values shown by the recommendations for conducting weaning (guidebook for supporting feeding and weaning, Ministry of Health, Labour and Welfare [5]).

\begin{tabular}{ccc}
\hline & $7-8$ months & $9-11$ months \\
\hline I Grains & $\begin{array}{c}\text { Soft boiled rice } \\
50-80 \mathrm{~g} \times 2\end{array}$ & $\begin{array}{c}\text { Soft boiled rice } 90 \mathrm{~g} \times 3 \\
- \text { Rice gruel } 80 \mathrm{~g} \times 3\end{array}$ \\
II Vegetables Fruits & $20-30 \times 2$ & $30-40 \mathrm{~g} \times 3$ \\
Fish & $10-15 \mathrm{~g}$ & $15 \mathrm{~g}$ \\
Meat & $10-15 \mathrm{~g}$ & $15 \mathrm{~g}$ \\
III $\quad$ Tofu & $30-40 \mathrm{~g}$ & $45 \mathrm{~g}$ \\
& Eggs & $-1 / 3$ of entire egg \\
Dairy & $50-70 \mathrm{~g}$ & $1 \mathrm{egg}$ \\
products & & $80 \mathrm{~g}$ \\
\hline
\end{tabular}

calculated for each type of weaning formula prepared for infants (with or without breast milk), and fulfilment rates (FRs) for energy and nutrients were estimated as percentages of the mean values relative to the respective target intake levels.

The nutrient contents of the formulas with $100 \%$ DRI for pantothenic acid, vitamin $\mathrm{D}$, iron or protein were also evaluated in terms of FR, with a particular focus on nutrients providing a $\mathrm{FR}$ of $\leq 80 \%$ or $\geq 200 \%$.

\subsection{Evaluation by Nutritional Components}

To evaluate issues that arose in formulas on the basis of the Standard Tables of Food Composition [6], the contents of pantothenic acid, vitamin D (except in vegetables), and iron vs. energy and protein in fish, meat, and vegetables (except processed foods) were examined.

\subsection{Statistical Procedure}

Data were analyzed using the SPSS (version 17.0, SPSS Inc., 2008). The relationships among the contents of pantothenic acid, vitamin D (except in vegetables), iron, energy, and protein in fish, meat, and vegetables (except processed foods) were evaluated using Spearman's rank correlation coefficient.

\section{Results}

\subsection{Hospital Formula}

The food-group contents of the hospital formulas for infants were larger than the target values recommended in the weaning guidelines [5], except for the group I (grains) content of the formula for 9 - 11-month-old infants. The volume of breast milk was $900.0 \mathrm{ml} /$ day in 6 8 -month-old infants and $850.0 \mathrm{~mL} /$ day in 9 - 11-month- old infants (Table 3).

In these formulas, the FRs of energy and protein exceeded $100 \%$, and those of vitamin $\mathrm{D}$ and iron were below $80 \%$, while those of vitamins $\mathrm{A}$ and $\mathrm{K}$ were more than 200 and $900 \%$, respectively (Table 4). Although the fat/energy ratios of the formulas were below the target levels, their fat contents were higher than the target values.

\subsection{Formula Based on the Weaning Guidelines}

Since the amounts of food for 6 - 8-month-old infants were the lower limits of the recommended values shown in the weaning guidelines, [5] the grain content was $160.2 \pm 2.1 \%$, but the value calculated using the higher limits was $100.1 \pm 0.3 \%$. In 9 - 11-month-old infants, the grain content calculated using the higher limits of recommended values was $51.4 \pm 4.7 \%$, but that calculated using the lower limits was $82.2 \pm 2.8 \%$. The contents of food groups other than grains conformed to the guidelines. The amount of breast milk was $600.0 \mathrm{ml} /$ day in 6 8-month-old infants and $448.0 \mathrm{ml} /$ day in 9 - 11-monthold infants (Table 3). The FRs of vitamins $\mathrm{B}_{1}, \mathrm{~B}_{6}, \mathrm{D}$, pantothenic acid, and iron were below $80 \%$, whereas that of vitamin K exceeded $700 \%$ in the formulas for infants (Table 4). In our previous study [4], the formulas based on weaning guidelines did not satisfy the recommended manganese intake of the DRIs-2005 [2]; however, in this study, the formulas achieved a FR of above $80 \%$ for manganese, because the manganese DRI in the 2010 version [1] has been reduced to less than one-half of the previous value.

\subsection{Conformity Formula}

The number of food items used per day was $6.5 \pm 0.5$ in 6 - 8-month-old infants and 7.9 \pm 1.1 in 9 - 11-month-old infants. These food items included brown rice, Egyptian spinach (Corchorus olitorius), cauliflower, eel liver, eel (cultured), chicken liver, and chicken tenderloin; namely, foods that could concomitantly provide high amounts of pantothenic acid, vitamin D, and iron. The amount of breast milk was $600.0 \mathrm{ml} /$ day in 6 - 8 -month-old infants and $450.0 \mathrm{ml} /$ day in $9-11$-month-old infants (Table 3). In addition, the daily use of sesame, green laver, and Jew's ear fungus was necessary. To achieve the target intake levels required amounts that could not be consumed by 6 - 8-month-old infants.

Although the formulas for both 6 - 8 and 9 - 11-monthold infants met the DRI-2010 [1] for every nutrient, they showed a FR of about $200 \%$ for several nutrients, including most prominently vitamin $\mathrm{K}$, while the FRs of pantothenic acid, vitamin $\mathrm{D}$, and iron barely exceeded 100\% (Table 4). 
Table 3. Amount of foods provided in the sample menus relative to that proposed in the recommendations for conducting weaning and daily values of food items.

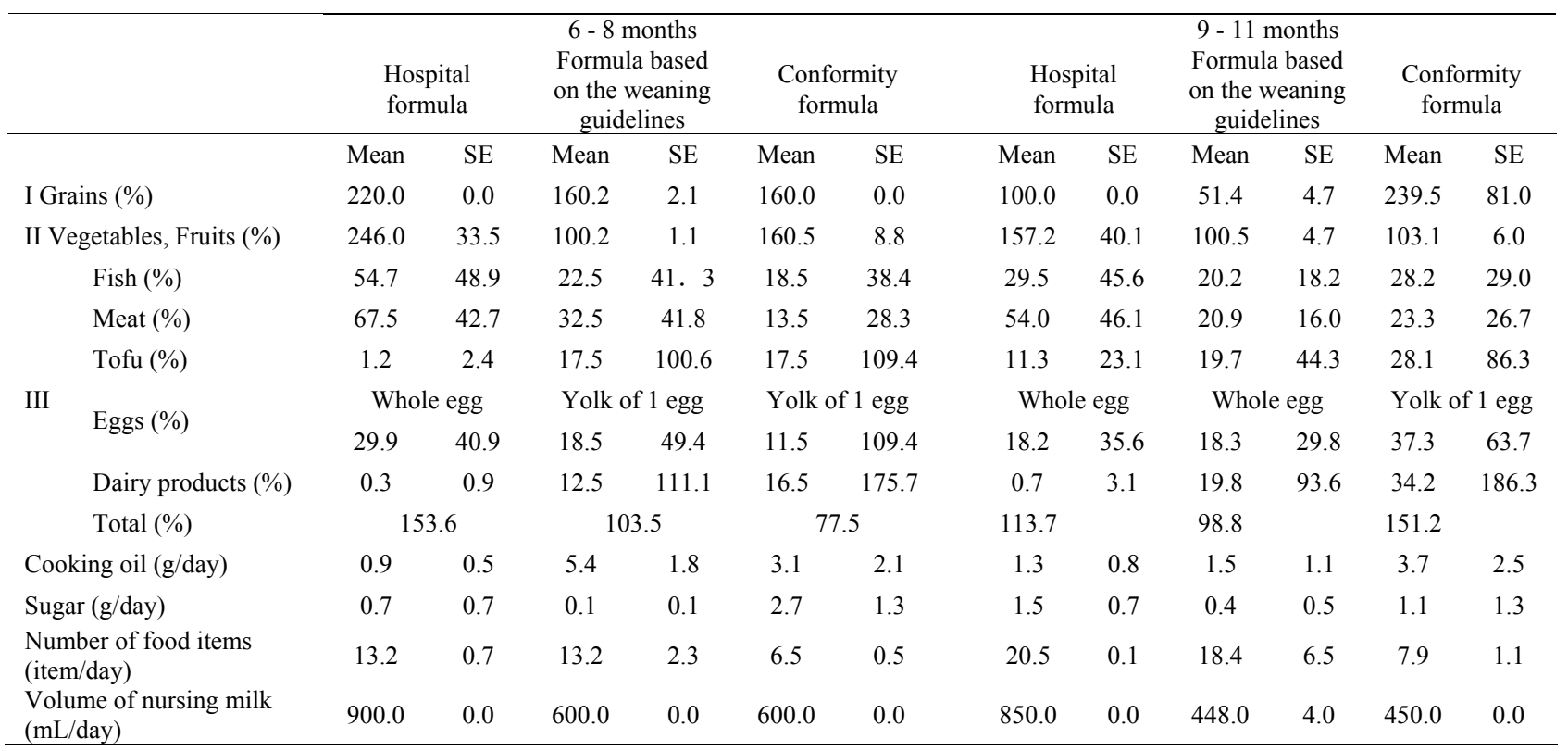

The amounts of food items contained in the formula based on the weaning guidelines were calculated using the lower (lowest) of the values recommended for 7 - 8-month-old infants and using the higher (highest) of the values recommended for 9 - 11-month-old infants.

Table 4. Mean energy and nutrient content of the sample formulas consisting of foods and breast milk (\%).

\begin{tabular}{|c|c|c|c|c|c|c|}
\hline & \multicolumn{2}{|c|}{ Hospital formula } & \multicolumn{2}{|c|}{$\begin{array}{l}\text { Formula based on the } \\
\text { weaning guidelines }\end{array}$} & \multicolumn{2}{|c|}{ Conformity formula ${ }^{*}$} \\
\hline & $6-8$ months & $9-11$ months & $6-8$ months & $9-11$ months & $6-8$ months & $9-11$ months \\
\hline Energy & $150.7(64.7)$ & $158.3(56.9)$ & $100.6(64.6)$ & $100.7(44.8)$ & $100.3(64.8)$ & $100.2(45.0)$ \\
\hline Protein & $141.3(46.7)$ & $106.4(37.2)$ & $100.0(44.0)$ & $67.7(29.2)$ & $100.8(43.7)$ & $100.4(19.9)$ \\
\hline Fat/energy ratio & 93.6 & 86.2 & 100.0 & 100.0 & 148.4 & 137.6 \\
\hline Vitamin $B_{1}$ & $83.3(36.0)$ & $110.0(27.3)$ & $55.5(36.1)$ & $63.7(23.5)$ & $119.7(16.7)$ & $111.7(14.9)$ \\
\hline Niacin & $136.7(43.9)$ & $193.3(31.0)$ & $107.1(37.4)$ & $89.0(33.6)$ & $149.3(26.8)$ & $153.7(19.5)$ \\
\hline Vitamin $\mathrm{B}_{6}$ & $93.3(0.0)$ & $136.7(0.0)$ & $61.4(0.0)$ & $71.3(0.0)$ & $142.7(0.0)$ & $172.7(0.0)$ \\
\hline Folic acid & $138.5(0.0)$ & $193.8(0.0)$ & $103.2(0.0)$ & $111.5(0.0)$ & $319.2(0.0)$ & $258.5(0.0)$ \\
\hline Vitamin $B_{12}$ & $133.3(0.0)$ & $183.3(0.0)$ & $23.4(0.0)$ & $126.7(0.0)$ & $321.7(0.0)$ & $313.3(0.0)$ \\
\hline Pantothenic acid & $116.4(77.3)$ & $123.6(73.2)$ & $75.8(79.1)$ & $65.0(69.0)$ & $102.4(58.6)$ & $112.1(40.1)$ \\
\hline Vitamin $\mathrm{C}$ & $195.0(57.7)$ & $220.6(51.1)$ & $115.7(64.8)$ & $123.0(45.6)$ & $177.3(42.3)$ & $282.8(20.3)$ \\
\hline Vitamin E & $140.0(73.5)$ & $151.4(67.9)$ & 110.7 (61.9) & $103.7(49.5)$ & $192.3(35.7)$ & $120.9(42.6)$ \\
\hline Vitamin D & $74.0(73.0)$ & $72.0(75.0)$ & $42.6(84.5)$ & $49.0(55.0)$ & $103.2(34.9)$ & $109.6(25.5)$ \\
\hline Vitamin $\mathrm{K}$ & $942.9(13.6)$ & 1,357.1 (9.5) & $742.5(11.5)$ & $854.3(7.5)$ & $5,638.6(1.5)$ & $1,330.0(5.4)$ \\
\hline Magnesium & $113.3(39.7)$ & $148.3(30.3)$ & $77.5(38.7)$ & $92.3(24.3)$ & $231.0(13.0)$ & $211.0(11.1)$ \\
\hline Calcium & $127.2(76.4)$ & $137.6(70.6)$ & $86.8(74.7)$ & $98.4(49.3)$ & $157.9(41.0)$ & $150.2(32.5)$ \\
\hline Phosphorus & $160.8(30.1)$ & $140.0(34.6)$ & $79.2(40.8)$ & $103.2(23.4)$ & $122.9(26.3)$ & $169.2(14.3)$ \\
\hline Manganese & $174.0(0.0)$ & $234.0(0.0)$ & $89.9(0.0)$ & $127.2(0.0)$ & $413.0(0.0)$ & $273.8(0.0)$ \\
\hline Iron & $37.8(21.2)$ & $53.3(15.0)$ & $22.3(23.9)$ & $32.4(12.3)$ & $100.2(4.4)$ & $100.4(4.4)$ \\
\hline Copper & $156.7(57.4)$ & $190.0(47.4)$ & $117.0(51.3)$ & $120.0(37.4)$ & $191.7(31.3)$ & $140.7(33.2)$ \\
\hline Zinc & $140.0(64.3)$ & $166.7(54.0)$ & $94.0(63.8)$ & $102.7(41.7)$ & $108.3(55.4)$ & $126.7(36.8)$ \\
\hline Potassium & $142.3(43.4)$ & $172.6(35.8)$ & $80.6(51.1)$ & $96.1(32.0)$ & $110.8(37.1)$ & $155.9(19.8)$ \\
\hline
\end{tabular}

*Formula designed to maximally follow the DRI for every nutrient. Percentages of each nutrient derived from breast milk are shown in parentheses. 


\subsection{Formulas with $100 \%$ DRI for Pantothenic Acid, Vitamin D, or Iron (for Both Age Groups), or Protein (for Infants Aged 9 - 11 Months)}

Among a total of six formulas that each satisfied the pantothenic acid, vitamin D and iron DRIs for infants, a FR of below $80 \%$ was observed in three formulas for pantothenic acid, in four formulas for vitamin $\mathrm{D}$, and in four formulas for iron. The three types of formulas with $100 \%$ DRI for pantothenic acid, vitamin D, or iron for 9 11-month-old infants did not fulfil the protein DRI, while all the seven types of formulas contained a markedly large amount of vitamin K with a FR of above $800 \%$
(Table 5).

\subsection{Evaluation by Nutritional Components}

The energy content showed positive correlations $(p<$ $0.01)$ with the contents of pathtothenic acid in fish and vegetables ( $r=0.413$ and 0.498 , respectively), vitamin D in fish $(r=0.658)$, and iron in vegetables $(r=0.227)$ and negative correlations $(p<0.01)$ with the contents of pantothenic acid $(r=-0.446)$ and iron $(r=-0.376)$ in meat.

The protein content showed positive correlations with the contents of pantothenic acid $(r=0.398$ and 0.679, respectively) and iron ( $r=0.248$ and 0.696 , respectively) in meat and vegetables and vitamin D in fish $(r=0.440)$

Table 5. Development of conformity formula for infants aged 6 - 8 months (1) and 9 - 11 months (2).

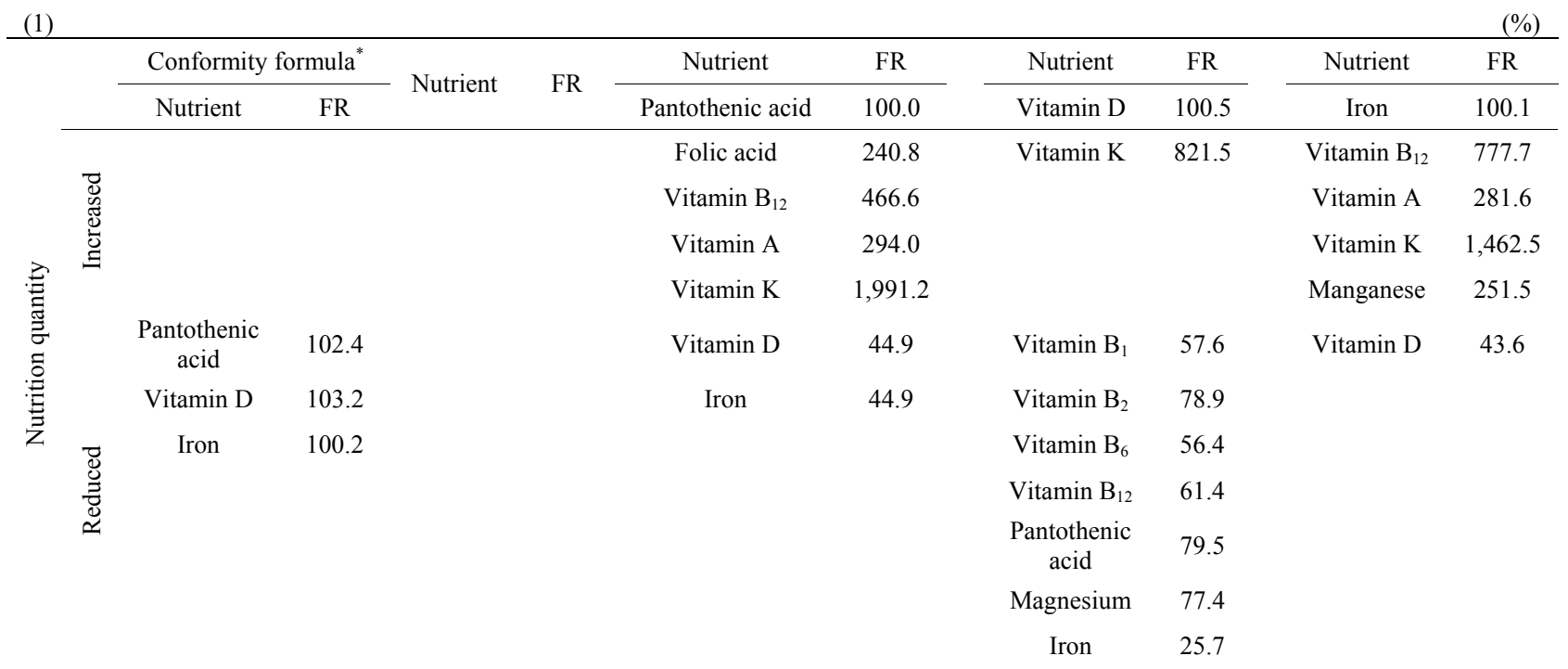

(2)

\begin{tabular}{|c|c|c|c|c|c|c|c|c|c|c|}
\hline & \multicolumn{2}{|c|}{ Conformity formula ${ }^{*}$} & \multirow{2}{*}{$\begin{array}{l}\text { Nutrient } \\
\text { Protein }\end{array}$} & \multirow{2}{*}{$\frac{\text { FR }}{100.0}$} & \multirow{2}{*}{$\begin{array}{c}\text { Nutrient } \\
\begin{array}{c}\text { Pantothenic } \\
\text { acid }\end{array}\end{array}$} & \multirow{2}{*}{$\begin{array}{c}\text { FR } \\
100.5\end{array}$} & \multirow{2}{*}{$\begin{array}{c}\text { Nutrient } \\
\text { Vitamin D }\end{array}$} & \multirow{2}{*}{$\begin{array}{c}\mathrm{FR} \\
103.9 \\
\end{array}$} & \multirow{2}{*}{$\begin{array}{c}\text { Nutrient } \\
\text { Iron } \\
\end{array}$} & \multirow{2}{*}{$\begin{array}{c}\text { FR } \\
103.2 \\
\end{array}$} \\
\hline & Nutrient & FR & & & & & & & & \\
\hline \multirow{6}{*}{ 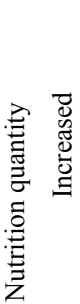 } & & & Niacin & 336.2 & Folic acid & 359.0 & Vitamin K & 828.5 & Vitamin $B_{12}$ & $1,027.8$ \\
\hline & & & Vitamin $\mathrm{B}_{6}$ & 234.6 & Vitamin $B_{12}$ & 533.0 & & & Vitamin A & 205.0 \\
\hline & & & Folic acid & 290.5 & Vitamin C & 215.6 & & & Vitamin K & $1,210.2$ \\
\hline & & & Vitamin K & $1,894.3$ & Vitamin A & 368.0 & & & & \\
\hline & & & Magnesium & 225.8 & Vitamin $\mathrm{K}$ & $3,081.5$ & & & & \\
\hline & & & Manganese & 411.7 & Manganese & 313.7 & & & & \\
\hline \multirow{4}{*}{ 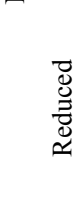 } & Protein & 100.4 & Iron & 60.7 & Protein & 78.4 & Protein & 70.9 & Protein & 71.9 \\
\hline & $\begin{array}{l}\text { Pantothenic } \\
\text { acid }\end{array}$ & 112.1 & & & Vitamin D & 46.2 & Vitamin $B_{1}$ & 68.8 & $\begin{array}{l}\text { Pantothenic } \\
\text { acid }\end{array}$ & 72.0 \\
\hline & Vitamin D & 109.6 & & & Iron & 56.4 & $\begin{array}{l}\text { Pantothenic } \\
\text { acid }\end{array}$ & 69.0 & Vitamin D & 35.4 \\
\hline & Iron & 100.4 & & & & & Iron & 34.1 & & \\
\hline
\end{tabular}

The type of formulas were prepared by modifying the conformity formula to satisfy the $100 \%$ DRIs for either pantothenic acid, vitamin D, or iron (which were later found not to be fulfilled in the conformity formula), and the FR for other nutrients in the formulas were estimated as a percentage relative to the respective DRI. *Formula designed to maximally follow the DRI for every nutrient. 
(all $p<0.01)$ and a negative correlation $(p<0.01)$ with iron in fish $(r=-0.190)$.

\section{Discussion}

In this study, we evaluated whether formulas fulfilling the DRIs-2010 [1] for all nutrients and in conformity with the Guidebook for Supporting Feeding and Weaning [5] can be prepared for 6 - 11-month-old breast-fed infants. As a result, we found it impossible to prepare formulas that simultaneously fulfilled the DRIs and Guidebook for 6 - 8 or 9 - 11-month-old infants.

The mean amounts of breast milk estimated to be incorporated into the hospital formulas for infants were more than the reference values used as a basis for the 2010-DRIs [1] (600 and $450 \mathrm{~mL}$ for infants, respectively; Yoneyama et al. [7,8]), while those estimated for the formulas based on weaning guidelines and conformity formulas for both age groups were equal to the reference values, which were less than the values estimated by Nakano et al. [9] (approximately 680 and $520 \mathrm{~mL}$ for infants aged 7 and 9 months, respectively) and Heinig et al. [10] (646 mL for 9-month-old infants).

The AIs for vitamin A (for both age groups) and protein (for 9 - 11-month-old infants) have been increased compared to the DRIs-2005 [2], the vitamin A and protein contents in the formulas exceeded the target values. The hospital formulas did not fulfil the target level of vitamin D or iron, although they contained energy and protein in amounts more than the respective target levels. The DRI for vitamin D has been increased in the DRIs-2010 compared to the previous value, resulting in difficulty in satisfying the current DRI. In the DRIs-2010, the iron DRI has been reduced, but the value was not fulfilled in the hospital formulas. The hospital formula for infants aged $6-8$ months did not achieve the target levels of vitamins $\mathrm{B}_{1}$ and $\mathrm{B}_{6}$, while the formula satisfied that of pantothenic acid, because the formula incorporated a considerable amount of breast milk, a rich source of pantothenic acid (Table 4).

In the formulas based on weaning guidelines for infants, FRs of below 50\% were observed for vitamin D and iron, and FRs of below $80 \%$ were noted for vitamins $\mathrm{B}_{1}, \mathrm{~B}_{6}$, and pantothenic acid. Unlike the hospital formulas, the formulas based on weaning guidelines did not satisfy the target levels of pantothenic acid, with a FR of less than $65 \%$ in the formula for 9 - 11-month-old infants. To achieve the target intake level of protein $(15 \mathrm{~g})$, the formulas based on weaning guidelines for 6 - 8-month-old infants needed to incorporate low-protein foods from the groups II and III, resulting in low FRs for numerous nutrients (Table 4). On the other hand, with a higher target intake level of protein $(25 \mathrm{~g})$, the formulas based on weaning guidelines for infants aged 9 - 11 months required high-protein foods, thereby providing an increased variety of nutrients in amounts sufficient to fulfil the target levels. However, it was found to be difficult to achieve the target level of protein $(25 \mathrm{~g})$, even by increasing the amount of group III foods (protein sources) to a level exceeding the recommended group III intake described in the weaning guidelines [5]. The fulfilment of a protein content of $25 \mathrm{~g}$ would exceed the target level of energy.

The conformity formulas fulfilled the target level of every nutrient; however, the formulas were less likely to be applicable in practical settings because the formulas required the exclusive and regular selection of specific food items that can concomitantly provide high amounts of pantothenic acid, vitamin D, and iron, and thus, consisted of a limited number of food items. The FRs of vitamin D and iron were below $100 \%$ in the four types of formulas including the hospital formulas and formulas based on weaning guidelines for infants. The FRs of vitamins $\mathrm{B}_{1}, \mathrm{~B}_{6}$, and pantothenic acid were less than $80 \%$ in the formulas based on weaning guidelines for both age groups. The FR of vitamin K was above $700 \%$ in all the six types of formulas including the hospital formulas, formulas based on weaning guidelines, and conformity formulas for infants.

To further evaluate the relationship between the weaning guidelines and DRIs, we attempted to prepare formulas that would fulfil the DRIs of pantothenic acid, vitamin $\mathrm{D}$, iron, and protein for 9 - 11-month-old infants, which could not be fulfilled in the formulas based on the weaning guidelines. Formulas that fulfilled all DRIs could be prepared, but they were hardly ingestible.

Concerning nutritional components, also, contradictory selection of food items was necessary to fulfil the DRIs of pantothenic acid $(5 \mathrm{mg})$, vitamin D $(5 \mu \mathrm{g})$, and iron (4.5 mg) for $6-8$ and 9 - 11-month-old infants and the DRI of protein for 9 - 11-month-old infants $(25 \mathrm{~g})$. It was practically impossible to prepare a weaning formula that could simultaneously satisfy the DRIs-2010 for infants [1] according to the weaning guidelines [5], which was mainly due to markedly low FRs of pantothenic acid, vitamin D, and iron (for infants), and protein (for those aged 9 - 11 month), as well as moderately low FRs of vitamins $B_{1}$ and $B_{6}$, and a high FR of vitamin $K$. To fulfil the DRIs of all these nutrients, the energy intake inevitably exceeds the tolerable range.

Therefore, we evaluated the pantothenic acid, vitamin D, iron, energy, and protein contents of fish, meat, and vegetables excluding processed foods, using Spearman's rank correlation coefficient. If fish and vegetables with high pantothenic acid and vitamin D contents were selec- 
ted, the protein and energy contents became excessive for 6 - 8 and 9 - 11-month-old infants, respectively. If meat with high pantothenic acid and iron contents were selected to increase their intake, energy becomes deficient, and protein becomes excessive, for 6 - 8-month-old infants. In 9 - 11-month-old infants, if fish was selected to increase the iron content, the protein became deficient.

In the DRIs-2010 [1], the pantothenic acid AI was calculated based on the concentration of pantothenic acid in the mature breast milk of Japanese women [11] and the breast milk intake of infants aged $0-5$ months (0.78 L/day) [12-14].

The 2008 and earlier National Health and Nutrition Surveys [3] did not evaluate the nutrient intakes among infants. Furthermore, only a limited number of surveys have been conducted regarding the dietary intakes in these age groups [15-17], suggesting that the pantothenic acid DRI in the 2010 version [1] may poorly reflect the actual dietary intake of pantothenic acid. The protein AI for infants aged 9 - 11 months in the DRIs-2010 [1] was calculated by means of the following calculation scheme: protein AI was estimated based on dietary surveys on protein intake from weaning foods $[9,18]$. The protein AI in the DRIs-2010 [1] thus estimated is therefore more practical than that in the DRIs-2005 [2]; however, the value could not be fulfilled in a manner consistent with the weaning guidelines' [5] recommended food-group intake.

Although the EER for infants aged 9 - 11 months has been set lower than that for children aged $1-2$ and $3-5$ years, the protein AI for infants aged $9-11$ months $(25 \mathrm{~g})$ has been estimated as higher than the protein EARs for children aged $1-2$ and $3-5$ years ( 15 and 20 g, respectively), and equal to the EAR for children aged $6-7$ years.

As we reported previously [4], the contents of each nutrient in various food items do not differ between Japan and Canada. However, the Japanese DRIs for pantothenic acid (for infants) and protein (for those aged 9 11 months) are higher than those in other countries (Table 6(1)). $[1,19-28]$ The Japanese DRI for vitamin D is equal to or lower, the iron DRI is lower, the vitamin $\mathrm{K}$ DRI is slightly lower, and the vitamins $B_{1}$ and $B_{6}$ DRIs are similar to the respective DRIs in other countries.

As clearly shown by Table 6(2), the recommended

Table 6. Recommended nutrient intakes in Japan and other countries (1) and nutritional contents of various formulas (2).

\begin{tabular}{|c|c|c|c|c|c|c|c|c|c|}
\hline (Country) & (Month) & $\begin{array}{l}\text { Protein } \\
(\mathrm{g})\end{array}$ & $\begin{array}{l}\text { Vitamin } B_{1} \\
(\mathrm{mg})\end{array}$ & $\begin{array}{l}\text { Vitamin } B_{6} \\
(\mathrm{mg})\end{array}$ & $\begin{array}{l}\text { Pantothenic } \\
\text { acid(mg) }\end{array}$ & $\begin{array}{l}\text { Vitamin D } \\
(\mu \mathrm{g})\end{array}$ & $\begin{array}{l}\text { Vitamin } \mathrm{K} \\
(\mu \mathrm{g})\end{array}$ & $\begin{array}{l}\text { Iron } \\
(\mathrm{mg})\end{array}$ & (Year) \\
\hline \multirow[b]{2}{*}{ Japan } & $6-8$ & 15 & \multirow[b]{2}{*}{0.3} & \multirow[b]{2}{*}{0.3} & \multirow{2}{*}{ (1) of } & \multirow[b]{2}{*}{5} & \multirow[b]{2}{*}{7} & $\begin{array}{c}3.5 \\
\text { (estimated mean) }\end{array}$ & \multirow[b]{2}{*}{2010} \\
\hline & $9-11$ & 25 & & & & & & $\begin{array}{l}4.5 \\
\text { (recommended } \\
\text { amount) }\end{array}$ & \\
\hline WHO & $7-12$ & - & 0.3 & 0.3 & 1.8 & 5 & 10 & $\begin{array}{c}\text { Bioavailability } \\
6.2(15 \%) \\
7.7(12 \%) \\
9.3(10 \%) \\
18.6(5 \%)\end{array}$ & 2004 \\
\hline USA/Canada & $7-12$ & 13.5 & 0.3 & 0.3 & 1.8 & 5 & 2.5 & 11 & 1997 \\
\hline $\begin{array}{l}\text { United } \\
\text { Kingdom }\end{array}$ & $\begin{array}{c}7-9 \\
10-12\end{array}$ & $\begin{array}{l}13.7 \\
14.9\end{array}$ & $\begin{array}{l}0.2 \\
0.3\end{array}$ & $\begin{array}{l}0.3 \\
0.4\end{array}$ & 1.7 & 7 & 10 & 7.8 & 1991 \\
\hline $\begin{array}{l}\text { Germany- } \\
\text { Austria- } \\
\text { Switzerland }\end{array}$ & $4-12$ & $\begin{array}{c}10 \\
(6-12 \\
\text { months })\end{array}$ & 0.4 & 0.3 & 3 & 10 & 10 & 8 & 2000 \\
\hline Philippines & $6-12$ & 14 & 0.4 & 0.3 & - & 5 & 9 & 10 & 2002 \\
\hline $\begin{array}{l}\text { Australia- } \\
\text { New Zea- } \\
\text { land }\end{array}$ & $7-12$ & 14 & 0.3 & 0.3 & 2.2 & 5 & 2.5 & $\begin{array}{c}7 \\
\text { (estimated average } \\
\text { requirements) } \\
11 \\
\text { (recommended } \\
\text { dietary intake) }\end{array}$ & 2005 \\
\hline South Korea & $5-10$ & 25 & 0.4 & 0.5 & - & 10 & - & $\begin{array}{c}10 \\
\text { Biological values of } \\
\text { calorie intake }\end{array}$ & 1995 \\
\hline Vietnam & $6-11$ & $\begin{array}{c}21-25 \text { (7 - } 12 \\
\text { months) }\end{array}$ & 0.3 & 0.3 & - & 5 & 9 & $\begin{array}{l}12.4(10 \%) \\
9.3(15 \%)\end{array}$ & 2007 \\
\hline Indonesia & $0-1$ (year) & $12-15$ & $0.3-0.4$ & - & - & - & - & $3-5$ & 1994 \\
\hline \multirow{2}{*}{ Singapore } & $6-9$ & 17 & 0.32 & - & - & 10 & - & \multirow[b]{2}{*}{7} & \multirow{2}{*}{2003} \\
\hline & $9-12$ & 18 & 0.38 & - & - & 10 & - & & \\
\hline Thailand & $0-1$ (year) & NS- $1.8 \mathrm{~g} / \mathrm{kg}$ & $0.3-0.5$ & - & - & - & - & $6-8$ & 1988 \\
\hline
\end{tabular}


(2)

\begin{tabular}{|c|c|c|c|c|c|c|c|c|}
\hline (Formula) & (Month) & $\begin{array}{l}\text { Protein } \\
(\mathrm{g})\end{array}$ & $\begin{array}{l}\text { Vitamin } B_{1} \\
(\mathrm{mg})\end{array}$ & $\begin{array}{c}\text { Vitamin } \mathrm{B}_{6} \\
(\mathrm{mg})\end{array}$ & $\begin{array}{l}\text { Pantothenic } \\
\operatorname{acid}(\mathrm{mg})\end{array}$ & $\begin{array}{c}\text { Vitamin D } \\
(\mu \mathrm{g})\end{array}$ & $\begin{array}{c}\text { Vitamin } \mathrm{K} \\
(\mu \mathrm{g})\end{array}$ & $\begin{array}{l}\text { Iron } \\
(\mathrm{mg})\end{array}$ \\
\hline Hospital formula & & 21.2 & 0.25 & 0.28 & 5.82 & 3.7 & 66 & 1.7 \\
\hline $\begin{array}{l}\text { Formula based on the } \\
\text { weaning guidelines }\end{array}$ & $\begin{array}{c}6-8 \\
\text { months }\end{array}$ & 15.0 & 0.20 & 0.18 & 3.79 & 2.1 & 52 & 1.0 \\
\hline Conformity formula ${ }^{*}$ & & 15.1 & 0.36 & 0.43 & 5.12 & 5.2 & 395 & 4.5 \\
\hline Hospital formula & & 26.6 & 0.33 & 0.41 & 6.15 & 3.6 & 95 & 2.4 \\
\hline $\begin{array}{l}\text { Formula based on the } \\
\text { weaning guidelines }\end{array}$ & $\begin{array}{l}9-11 \\
\text { months }\end{array}$ & 16.9 & 0.19 & 0.21 & 3.25 & 2.5 & 60 & 1.5 \\
\hline Conformity formula ${ }^{*}$ & & 25.1 & 0.34 & 0.52 & 5.61 & 5.5 & 93 & 4.5 \\
\hline
\end{tabular}

NS, not stated; *Formula designed to maximally follow the DRI for every nutrient.

intakes of pantothenic acid and protein in the foreign guidelines can be fulfilled by the formulas based on weaning guidelines prepared in this study. In Canada, vitamins $\mathrm{B}_{1}$ - and $\mathrm{B}_{6}$-fortified or enriched wheat flour [29] and cereals [30] are rich sources of the vitamins. Similarly, in Canada, vitamin D-supplemented milk and infant vitamin supplements [31] are available, and ironfortified infant formulas has been recommended by the Dietitians of Canada [32]. These findings indicate that, in Japan, nutrition education for infant feeding practices should focus more on low fulfilment rates of vitamin $B_{1}$, $B_{6}, D$ and iron and encourage the selection of health foods, such as government-approved foods for specified health use, containing these nutrients.

\section{Conclusions}

These results demonstrate that it is practically impossible to prepare a weaning formula that can compatibly satisfy the DRIs-2010 for 6 - 8 and 9 - 11-month-old infants [1] and the weaning guidelines [5]. When determining the DRIs [1] and weaning guidelines [5], consideration should be given not only to medical and nutritional factors, but also to practical aspects of meal planning such as dietary patterns and food combinations.

\section{REFERENCES}

[1] Ministry of Health, "Labour and Welfare of Japan (2010) Dietary Reference Intake for Japanese," Daiichi Shuppan Publishing Co., Ltd., Tokyo, 2009.

[2] Ministry of Health, "Labour and Welfare of Japan (2005) Dietary Reference Intake for Japanese," Daiichi Shuppan Publishing Co., Ltd., Tokyo, 2005.

[3] Ministry of Health, "Labour and Welfare of Japan (2009) The National Health and Nutrition Survey in Japan," 2008.

http://www.mhlw.go.jp/houdou/2009/11/dl/h1109-1.html

[4] S. Tsutie, N. Kurihara, A. Sasaki, A. Takagi, H. Seguchi and T. Inatome, "Formulas Providing Adequate Pan- tothenic Acid, Vitamin D, Manganese, Iron and Vitamin A for Infants Fed with Mother's Milk (Aged 6-11 Months) According to the Japanese Dietary Reference Intakes Prepared by the Ministry of Health, Labour and Welfare (2005 Edition)," Maternal \& Child Nutrition, Vol. 6, No. 2, April 2010, pp. 147-158.

[5] Equal Employment/Children and Families Bureau, Ministry of Health, Labour and Welfare, "The Recommendations for Conducting Weaning in the Guidebook for Supporting Feeding and Weaning," Maternal and Child Health Division, Report No. 47, 2007.

[6] Ministry of Education, Culture, Sports, Science and Technology, "The 5th Supplemented Edition of the Standard Tables of Food Composition in Japan: Ed. Workshop of Food Composition,” Ishiyaku Publishers, Inc., Tokyo, 2006.

[7] K. Yoneyama, "Growth of Breast-Fed Infants and Intake of Nutrients from Breast-Milk," Japanese Society of Child Health, Vol. 57, No. 1, 1998, pp. 49-57.

[8] K. Yoneyama, I. Goto and H. Nagata, "Changes in the Concentrations of Nutrient Components of Human Milk during Lactation," Japanese Journal of Public Health, Vol. 42, No. 7, July 1995, pp. 472-481.

[9] T. Nakano, K. Kato, N. Kobayashi, et al., "Nutrient Intake from Baby Foods Infant Formula and Cow's Milk Results from a National-Wide Infant's Dietary Survey," Journal of Japanese Society of Child Health Nursing, Vol. 62, No. 6, November 2003, pp. 630-639.

[10] M. J. Heinig, L. A. Nommsen, J. M. Peerson, B. Lonnerdal and K. G. Dewey, "Energy and Protein Intakes of Breast-Fed Formula-Fed Infants during the First Year of Life and Their Association with Growth Velocity: The DARLING Study," The American Journal of Clinical Nutrition, Vol. 58, No. 2, August 1993, pp. 152-161.

[11] K. Shibata, et al., "Distribution of the Water-Soluble Vitamin Content of Japanese Breast Milk," Journal of Japanese Society of Nutrition and Food Sciences, Vol. 62, No. 4, 2009, pp. 179-184. doi:10.4327/jsnfs.62.179

[12] T. Watanabe, et al., "The Contents of Biotin, Pantothenic Acid and Niacin in Mature Milk of Japanese Women," Vitamins, Vol. 78, No. 8, 2004, pp. 399-407.

[13] K. Suzuki, et al., "Milk Intake by Breast-Fed Infants be- 
fore Weaning," Journal of the Japan Diabetes Society, Vol. 62, No. 6, 2004, pp. 369-372.

[14] J. Hirose, et al., "Amount of Breast Milk Sucked by Japanese Breast Feeding Infants," Journal of Japanese Society for Breast Feeding Research, Vol. 2, No. 1, 2008, pp. 23-28.

[15] T. Nishimura and S. Endo, "An Investigation on the Food of Infants from 3 Months to 17 Months after Birth in Matsue (Part1) - Concerning the Quantity of Nutrient and Food Intake," Japanese Society of Child Health, Vol. 43, No. 1, 1984, pp. 57-65.

[16] Y. Okuma, et al., "A Survey of Nutrition of Infants in Takatsuki City," Journal of Japanese Society of Child Health Nursing, Vol. 49, No. 6, November 1990, pp. 676685.

[17] T. Nakano, T. Idota and I. Nakajima, "The National Survey of Nutrient Intake from Weaning Food in Japan," Journal of Pediatric Gastroenterology and Nutrition, Vol. 9, No. 1, 1995, pp. 16-27.

[18] T. Hokama, Y. Asato and S. Nakazato, "Nutritional Survey of Intake during Late Weaning Period in Nakagusuku Village, Okinawa," Journal of Japanese Society of Child Health Nursing, Vol. 57, No. 1, January 1998, pp. 45-48.

[19] Institute of Medicine of the National Academies, "Dietary Reference Intakes," 1997. http://www.iom.edu/Global/News\%20Announcements/ / media/Files/Activity\%20Files/Nutrition/DRIs/DRISummaryListing2.ashx

[20] Republic of Korea, "Implementation of the International Covenant on Economic, Social and Cultural Rights," 1999. http://www.mfa.gov.af/Documents/HR-Reports/CESCRAfghanistan.pdf

[21] C. V. C. Barba and M. I. Z. Cabrera, "Recommended Energy and Nutrient Intakes for Filipinos 2002," Asia Pacific Journal of Clinical Nutrition, Vol. 17, Supplement 2, 2008, pp. 399-404.

[22] World Health Organization and Food and Agriculture Organization of the United Nations, "Vitamin and Mineral Requirements in Human Nutrition," 2nd Edition, Wor- ld Health Organization, Hong Kong, 2004, pp. 338-341.
[23] Health Canada, "Dietary Reference Intakes," 2010. http://www.hc-sc.gc.ca/fn-an/alt_formats/hpfb-dgpsa/pdf/ nutrition/dri_tables-eng.pdf

[24] German Nutrition Society, Austrian Nutrition Society, Swiss Society for Nutrition Research, "Reference Values for Nutrient Intake (D-A-CH)," 2000.

http://www.dge.de/modules.php?name $=$ Content\&pa $=$ sho wpage\&pid=3

[25] Ministry of Health, Labour and Welfare of Japan, "Sixth Revision of Recommended Dietary Allowances - Dietary Reference Intake," Daiichi Shuppan Publishing Co., Ltd., Tokyo, 1999.

[26] Health Promotion Board Online, "Recommended Daily Dietary Allowances for Normal Healthy Persons in Singapore," 2003.

http://www.hpb.gov.sg/foodforhealth/article.aspx?id=265 2\&lifestage $=$ Infant

[27] N. C. Khan and P. V. Hoan, "Vietnam Recommended Dietary Allowances 2007," Asia Pacific Journal of Clinical Nutrition, Vol. 17, Supplement 2, 2008, pp. 409-415.

[28] The Australian Government, "Nutrient Reference Values for Australia and New Zealand Including Recommended Dietary Intakes," 2005.

http://www.nhmrc.gov.au/_files_nhmrc/file/publications/s ynopses/n35.pdf

[29] N. Tasnim, P. Christina and O. Aleck, "An Analysis of the Development of Canadian Food Fortification Policies: The Case of Vitamin B," Health Promotion International, Vol. 20, No. 4, 2005, pp. 375-381. doi:10.1093/heapro/dai015

[30] Health Canada Web Site, 1999. http://webprod.hc-sc.gc.ca/cnf-fce/search-rechercher.do?1 ang=eng

[31] Indian and Inuit Health Committee, Canadian Paediatric Society, "Vitamin D Supplementation for Northern Native Communities," Canadian Medical Association Journal, Vol. 138, 1998, pp. 229-230.

[32] S. M. Innis, et al., "Incidence of Iron-Deficiency Anaemia and Depleted Iron Stores among Nine-Month-Old Infants in Vancouver, Canada," The Canadian Journal of Public Health, Vol. 88, No. 2, 1997, pp. 80-88. 